\title{
РЕПРЕЗЕНТАЦІЯ ТОМОСУ ПРО АВТОКЕФАЛІЮ ПРАВОСЛАВНОЇ ЦЕРКВИ УКРАЇНИ У ПРЕСІ
}

\author{
Оксана Гоцур \\ Львівський національний університет імені Івана Франка, \\ вул. Генерала Чупринки, 49, 79044, Львів, Україна \\ e-mail: o hotsur@ukr.net \\ https://orcid.org/0000-0002-6589-0011
}

У статті проаналізовано концепт томосу на сторінках загальноукраїнських періодичних видань. З’ясовано парадигму проблеми преси щодо висвітлення та акцентуації журналістами питання автокефалії Православної Церкви України. Розглянуто інформаційну та жанрову специфіку, характер публікацій.

Ключові слова: преса, концепт, публікація, автокефалія, томос, Православна церква України, ПЦУ (КП), ПЦУ (МП).

Актуальність дослідження. Надання томосу про автокефалію Православної Церкви України - подія загальнодержавного та загальнонаціонального значення 3 одного боку, а з іншого - геополітично значуща як для України так і для православного християнства. Це один із ключів до глибшого подальшого успішного державотворення в Україні. Преса, як дзеркало відображення усіх процесів, пов'язаних і 3 цією подією, мала б відіграти важливу роль в їі інформуванні, розв’язанні, аналізі для того, щоб українське суспільство ці процеси зрозуміло, сприйняло та адекватно реагувало. Це неабияк важливо з огляду на поліконфесійність та багаторічного існування розколу православ’я на три гілки: УПЦ (КП), УПЦ (МП), УАПЦ.

Історіографію дослідження становлять журналістикознавчі праці, в яких розглянуто релігійну проблематику у пресі та самі релігійні видання.

Українське журналістикознавство з релігійної проблематики становлять праці кінця XIX - поч. XX ст., праці періоду Незалежності та діаспорні дослідження. Релігійну проблематику піднімали I. Франко, Б. Кістяківський, М. Міхновський, С. Петлюра та ін.

У діаспорі свої погляди на релігію мали такі українські публіцисти та діячі, як М. Шлемкевич, В. Липинський, Ю. Вассиян, Р. Рахманний, І. Лисяк-Рудницький та ін. Зокрема, на думку І. Лисяка-Рудницького, Україна розташована між двома світами греко-візантійської й західної культур і законний член їх обох, завжди прагнула синтезувати ці дві традиції. Водночас автор наголошує на європейськості країни: «Україна «західня» остільки, постільки вона становить органічну складову частину Європейської спільноти народів» [1, с.10]. Але зауважує, що в національно-культур-

(C) Гоцур О., 2019 
ному характері існують сильні «незахідні» елементи, що зумовлено релігійним вибором князя Володимира Великого.

Натомість В. Липинський стверджував, що корені візантійського православ'я ближчі до коренів римських, на відміну від «удержавленого синодального православ'я всеросійського» [2, с. 66]. Під «римським корінням» він розумів виросле 3 того коріння дерево католицизму. «Маючи в своїй нації і Схід і Захід, і одну і другу церкву, і один та другий - то ці то інші форми приймаючий і сам в собі переможний історичний напрям - ми мусимо, коли хочемо бути нацією, ці два напрями під гаслом єдности та індивідуальности нашої національної в собі весь час гармонізувати. Без такої гармонізації ми гинемо як нація: підпадаєм - не завойовані ніким чужою зброєю, а завжди власним внутрішнім розкладом - під впливи то східної Москви, то західної Польщі» [2, с. 66].

«Вплив на Україну з боку католицького Заходу і візантійського Сходу» - саме таку проблему порушує Ю. Вассиян в іншій праці: «Простір між Москвою і Візантією». Розглядаючи ці два протилежні релігійні світогляди, публіцист віддає перевагу Заходу католицькій церкві перед Сходом (Візантією) і відповідно східним християнством. На відміну від Заходу «в основі візантійської держави не жив і не творив один центральний антропологічний тип», адже «життя східно-римського цісарства - це властиво повільне конання в атмосфері найвищої штучності зовнішніх форм блиску, в яких уже не було тіні монументальної величі, простоти й силової дійсности римського духа» [3, с. 269].

У період незалежності мало б появитися кількісно і якісно більше наукових розвідок. Насамперед потрібно зауважити, що авторами більшості наразі виданих досліджень, є наукові розвідки С. Костя, М. Лозинського, І. Скленара, А. Юраша, М. Балаклицького та ін. 3-поміж новіших досліджень, наприклад, виділимо праці Ю. Лавриш, А. Кліща, Н. Гадьо.

Окрему групу наукових розвідок становлять праці, в яких окреслено специфіку, проблемний характер функціонування релігійної проблематики в соціальних комунікаціях. Це, зокрема, праці А. Бойко, О. Мігай, Ю. Комінка.

Джерельна база дослідження - це всеукраїнські видання суспільно-політичного характеру: «Дзеркало тижня», «День», «Україна молода», «Молодь України», та офіційні друковані органи: «Урядовий кур'єр», «Голос України».

Завдання дослідження полягає в тому, щоб 1) визначити характерні особливості у висвітленні концепту томосу у всеукраїнських суспільно-політичних та офіційних друкованих виданнях; 2) окреслити проблеми преси з релігійної проблематики.

Мeта - з'ясувати специфіку відображення у пресі проблеми надання автокефалії Православної Церкви України.

Вручення Вселенським Патріархом Томосу про автокефалію Православної Церкви України, безумовно, є подією важливою у житті українського суспільства. Але також і для нашого північного сусіда - Російської Федерації, про що свідчить повне несприйняття цієї події російським політикумом.

Всі процеси і події, пов’язані з отриманням томосу висвітлювала та аналізувала преса. У цілому ж тема автокефалії стала актуальною для журналістів та релігійних оглядачів ще з квітня 2018 року, коли відбулися три важливі події. Перша, коли Президент України П. Порошенко у Стамбулі мав зустріч із Вселенським патріархом Варфоломієм. Друга, коли після цієї зустрічі президент на екстреній зустрічі 
із головами парламентських фракцій попросив Верховну Раду України підтримати звернення «президента і церковних ієрархів до Вселенському патріарха» щодо надання томосу українській православній помісній церкві. I третя - Вселенський патріарх розпочав розгляд цього прохання. До цих подій українська Церква є об'єктом обговорення в газетах, що було пов'язане насамперед із скандалами (про багатство та розкіш священнослужителів, про локальні внутрішньо церковні проблеми тощо). Про суспільно значиму та певну державотворчу роль Церкви почали говорити в період Євромайдану та військового вторгнення Росії на територію України. У цьому контексті цілком слушною є думка професора А. Бойко: «Якщо розглядати інформацію про Церкву і релігійну діяльність в Україні, то на першому місці в усіх мас-медіа - сенсаційні моменти 3 життя Церков і релігійних організацій; на другому такі проблеми: релігія (Церква) і держава, релігія (Церква) і політика... релігія (Церква) і націєтворчі процеси тощо» [4, с. 309].

Інтелектуальні всеукраїнські видання «День», «Дзеркало тижня» мають свою певну специфіку у відображенні теми автокефалії Православної Церкви України (надалі ПЦУ). Окремі характерні риси мають газети «Молодь України» й «Україна молода».

Урядові офіційні друковані органи «Голос України» та «Урядовий кур’єр» подають в основному матеріали інформаційного характеру у формі заміток, звітів, оприлюднення виступів перших осіб держави та перших церковних осіб, інтерв’ю 3 ними. Тут також можна прочитати повний текст Томосу про автокефалію ПЦУ. Але кількісно-якісні характеристики цих матеріалів досить незначні, зважаючи на важливість питання та можливості офіційних видань такого рангу. Зокрема, на сторінках «Урядового кур'єру» появилося аж 43 матеріали. Оглядачами релігійної проблематики у газеті є Лана Самохвалова, Катерина Мацегора, Юрій Медуниця.

Вже у квітні минулого року «Урядовий кур'єр» повідомляє, що «Україна близька до Помісної Церкви», що пов'язане із згаданими подіями.

До цього у ЗМІ зрідка обговорювали тему про те, що Українська Православна Церква передана під владу Москви неправомірно і неканонічно. Про це, зокрема, говорить єпископ УПЦ КП Євстратій Зоря в інтерв’ю «Урядовому кур'єру», котрий вже тоді зазначив: «Подї на Майдані, а потім боротьба з агресією сусідньої держави засвідчили, наскільки потрібна людям України власна віра, власна Церква» [5].

Повний текст Томосу про автокефалію ПЦУ розмістила на свої сторінках газета Верховної Ради України «Голос України» [6]. Релігійний оглядач С. Чорна перед текстом документу коротко повідомляє, що 14 січня 2019 року на офіційному сайті Вселенського патріархату оприлюднено текст Томосу трьома мовами: грецькою, англійською та українською. Окрім того, що він перекладений, оглядач зауважує, що його повна публікація зумовлена ще трьома чинниками: по-перше, увесь процес надання автокефалії став об'єктом маніпуляцій і фальсифікацій з боку російських та проросійських 3МI; по-друге, циркулює багато міфів про те, що митрополія передбачає повну залежність від Константинополя, що Томос про автокефалію ПЦУ не дійсний, бо підписаний не тими митрополитами; по-третє, сам текст документа піддається різним маніпуляціям і тлумаченням.

Газети «Молодь України» та «Україна молода» також мають певну специфіку у висвітлення теми автокефалії ПЦУ. Перше видання на своїх шпальтах скоріше інформувало про події, пов’язані з томосом, аніж аналізувало. Журналіст Ю. Брязгунов 
у матеріалі «Томос наближається: поступово, але твердо» (№ 41-42, 2018) акцентує увагу на подіях в українському політикумі навколо утворення Православної церкви України. Зокрема, на тиск на митрополита Епіфанія з боку Москви, на прохання Ю. Тимошенко до очільника Церкви сусідньої держави (у тексті не сказано конкретно, але можна здогадуватися, що це Росія) втрутитися, щоб Україні не надали Томосу. Звернено увагу на події, пов’язані із святинями, які знаходились у віданні УПЦ МП.

3 поміж матеріалів газети інформаційного характеру дещо вирізняється інший матеріал Ю. Брязгунова, написаний спільно О. Журавльовою, «Міжцерковні реалії: запитання й пошук істини» (Молодь України. 2018, № 32-33). Автори, опираючись на факти, шукають відповіді на питання: коли саме чекати вручення Томосу і чому саме зараз ця подія може бути зреалізована, чи зникне УПЦ МП після проголошення автокефалії, якою є реакція Російської православної Церкви і до чого це призведе.

Суспільно-політичне видання «Україна молода» більш грунтовно підходить до висвітлення теми автокефалії, аналізуючи та осмислюючи їі. Тут читаємо покрокові процеси, які передували отриманню Томосу: «На фініші до Томосу: хто і як очолить єдину Церкву в Україні» (Україна молода. 2018, № 123.), «Томос буде: головне про засідання Синоду Вселенського патріархату в Стамбулі» (Україна молода. 2018, №111), «Русскій мір» пручається: як депутати у Раді билися через московських попів» (Україна молода. 2018, № 140), «З Томосом, з духовною свободою: як Україна відсвяткувала історичне Різдво» (Украӥна молода. 2019, № 002).

Однією з ознак якісної преси є об’єктивність, а це означає для читача можливість прочитати думки другої сторони проблеми. Саме «Україна молода» 3-поміж досліджуваних видань дотримується цього принципу журналістики, адже опублікувала на своїх шпальтах інтерв’ Я. Музиченка «Протоірей УПЦ (МП) Андрій Дудченко: «Кожен із нас має звузити себе, щоб увійти в Церкву...» (Україна молода. 2018, № 136). Протоірей не лише розповів, якою бачить Помісну церкву («Це формування спільної християнської православної ідентичності в Україні...»), а й наголосив на ролі ЗМІ в інформуванні усіх церковних процесів щодо автокефалії ПЦУ: «Якісна інформаційна підтримка потрібна, щоб люди розуміли, що відбувається в Церкві, та як бути християнином у сучасному світі... Потрібна співпрачя духовенства 3 вірянами у спільній побудові Церкви, щоб знову не утворився клон тієї організації, яка сьогодні є».

Інші два якісні інтелектуальні всеукраїнські суспільно-політичні видання «День» і «Дзеркало тижня» аналітично підходять до висвітлення теми автокефалії української Церкви. Релігійний оглядач тижневика К. Щоткіна у статті «Просто автокефалія. Чому Томос справжній і навіщо він нам» (Дзеркало тижня. 2018, № 47) пояснює читачам, що таке автокефалія ПЦУ відповідно до вимог Вселенського патріархату, хто може очолити нову Церкву, а також тлумачить статті Статуту автокефалії Православної Церкви України, якими маніпулюють її противники (питання про підпорядкування Церкви, про канонізацію святих, про «національну Церкву», про підпорядкування українських православних в діаспорі). Зокрема, К. Щоткіна зауважує: «Головна різниия між автокефальною ПЦвУ та автономною УПЦ МП як між незалежною Украӥною, яка сама себе представляє на міжнародній арені, $i$ УРСР, яка на цій арені була представлена Радянським Союзом». Власне, на ії думку, Українській церкві необхідні внутрішні глобальні зміни, «адже й иерква наша така сама пострадянська структура, такий самий уламок системи...». 
Про недалекоглядність та певну обмеженість очільників УПЦ МП в умовах наближення проголошення Томосу К. Щоткіна говорить в іншій статті «Як єпископи УПЦ МП знову «не встали» (Дзеркало тижня. 2018, № 44). Авторка аналізує, чому єпископи УПЦ МП не прийшли на зустріч із П. Порошенком, який прагне діалогу на шляху до автокефалії ПЦУ.

Газета «День» не лише аналізує внутрішньополітичні події, пов'язані з томосом, а також шукає спільні корені українського православ’я з Константинополем, які були розірвані Росією, Церква якої насильно підпорядкувала собі Київську митрополію (Україна й Константинополь: тисячу років разом // День, 2018, № 230).

Релігійний оглядач «Дня» I. Капсамун цілком слушно вважає, що після отримання Томосу ще важливішою справою є розбудова об’єднаної Церкви («Православний ренесанс». Якою має бути нова Церква? // День. 2018, № 230). 3 цією статтею дещо суголосна інша «Що вирішує Томос?» (День. 2018, № 208-209), основними меседжами якої є: проблема помісної Церкви - це умова виживання України; Томос це становлення якісно іншого православ'я; надання українській Церкві автокефалії «допоможе повернути Україні Україну».

Потрібно зауважити, що досліджувані видання наголошують на важливість Томосу про автокефалію ПЦУ для подальшого успішного державотворчого процесу в Україні. Про це свідчать, зокрема такі матеріали, як «Автокефалія Української Церкви - фактично ще один акт проголошення незалежності» (Голос України 13.10.2018), «Томос та автокефалія - питання нашої незалежності» (Голос Украї$н и-17.10 .2018)$, «Томос - другий акт проголошення державної незалежності» (Голос України - 29.12.2018), «Завдяки Порошенку Україна вперше за 1030 років від хрещення отримає автокефалію» (Україна молода. 2018, № 132), «Просто автокефалія. Чому Томос справжній і навіщо він нам» (Дзеркало тижня. 2018, № 47).

Таким чином можна виділити концепт томосу в газетних матеріалах - друга незалежність.

Ще один концепт формується у контексті осмислення журналістами першоджерела українського православ'я, для якого Вселенська православна церква є материнською (Міжцерковні реалії: запитання й пошук істини // Молодь України. 2018. № 32-33; «Як єпископи УПЦ МП знову «не встали» // Дзеркало тижня. 2018, № 44, «Що вирішує Томос?» // День. 2018, № 208-209). Цей концепт вибудовується на з'ясуванні канонічності/ неканонічності Православної церкви України. Зокрема, у статті Г. Омельченка «Хрестовий похід» Кремля: як Московія привласнила православ’я Київської Русі та чому не хоче його втрачати» закцентовано увагу на постаті патріарха РПЦ Кирила, на неканонічності РПЦ, про що говорить і сам Вселенський патріарх (Україна молода. 2018, № 120). Автор вважає: «Міф «Москва - Третій Рим» луснув, як мильна бульбашка завдяки рішенню України та Вселенської Церкви отримати духовну незалежність».

Про томос видання говорили не лише з погляду важливості внутрішньоукраїнських релігійних та суспільно-політичних реалій, а й з погляду геополітики. Концепт геополітики знаходимо у матеріалах Томос - другий акт проголошення державної незалежності // Голос України. 2018. 29 груд; Подія, на яку ми чекали понад тисячоліття // Молодь України. 2019, № 1-2; Біситься не на жарт. Росія готувала провокації напередодні Об’єднавчого Собору // Україна молода. 2018, № 137, Україна, церква і світ після правди // Дзеркало тижня. 2018, № 50. Геополітичну важливість 
території України для Росії власне засвідчила реакція Кремля на прагнення держави здобути автокефалію для Української православної Церкви. На цьому наголошує релігійний оглядач «України Молодої» К. Щаслива у статті «Завдяки Порошенку Україна вперше за 1030 років від хрещення отримає автокефалію» (Україна Молода. 2018, № 132). На її думку, власне Томос $є$ тим інструментом, яким Україна зможе дати гідну відсіч російській владі за намагання через церкву втручатися у внутрішньополітичні події держави. I мова йде не тільки про те, що керівники УПЦ МП зневажливо ставляться до української державності, зауважує автор, дають добро на освячення зброї для ведення війни на території України, а й те, що питання про автокефалію ПЦУ розглядалося на найвищому рівні РФ. Оглядач підсумовує: «Надання Украӥнській церкві Томосу про автокефалію експерти називають іще одним Актом проголошення незалежності України, який став логічним продовженням стратегічного курсу Пороченка на переорієнтацію Росії на Європу і повного виходу України зі сфери імперського впливу Москви».

Про нові можливості, якими потрібно якісно правильно скористатися у подальшому державотворенні читаємо на шпальтах «Дзеркала тижня»: «Останні 27 років Україна регулярно перебувала в пошуку нового початку, чистого аркуша. Шанси приходили й зникали, але рішучого прориву не було. Поява повноцінної Помісної церкви на чолі з 39-річним сучасним лідером, із заступництвом матері-церкви в Константинополі - це ще одні двері, які відчиняє перед нами історія» (Украӥна, церква $i$ світ після правди // Дзеркало тижня. 2018, № 50). Таким чином можна виокремити концепт «новий початок».

Концепт історичної спільності як тяглості культурно-релігійної традиції України і Константинополя простежується у матеріалі «Україна й Константинополь: тисячу років разом» (День - 2018, № 230).

Як можна побачити, питання автокефалії Української Церкви преса розглядає найчастіше через бінарні опозиції «Томос - «русскій мір» «Україна - Росія», «УПЦ КП - УПЦ МП».

Огляд та аналіз всеукраїнських суспільно-політичних видань «День», «Дзеркало тижня», «Україна молода», «Молодь України», офіційних друкованих органів «Голос України», «Урядовий кур'єр» показав специфіку висвітлення теми Томосу про автокефалію Православної Церкви України. Сплеск матеріалів у виданнях, пов'язаний із всіма процесами до найголовнішої події - отримання Томосу, тобто офіційного визнання права на власну Церкву з рук Вселенського патріархату. Після цієї події зацікавленість темою різко знижується, що суголосне із загальною динамікою висвітлення теми в усіх українських мас-медіа. Тобто принцип сенсаційності у висвітленні релігійної тематики, який виокремила професор А. Бойко, працює.

\section{REFERENCES}

1. Лисяк-Рудницький I. Україна між Сходом і Заходом / І. Лисяк-Рудницький / Історичні есе. К., 1994. Т.1. С. 1-10.

2. Липинський В. Липинсьий В. Релігія і церква в історії України / В. Липинський. Київ : Рада, 1995. 94 с.

3. Вассиян Ю. Простір між Москвою і Візантією / Ю. Вассиян // Твори. Торонто, 1972. Т. 1. : Степовий Сфінкс: суспільно-філософічні нариси. 490 с. 
4. Бойко А. Релігія і політика медіа: особливості сприйняття інформації молодіжною аудиторією / А. Бойко // Збірник праць Науково-дослідного інститу пресознавства. 2013. Вип. 3. С. 307-319. Режим доступу: http://nbuv.gov.ua/UJRN/ ZPNDZP_2013_3_27

5. Самохвалова $\bar{Л} . \bar{Є}$ Сископ Євстратій Зоря: «Київську метрополію передали під владу Москви неканонічно» / Л. Самохвалова // Урядовий кур'єр. 2014. 11 лип.

6. Чорна С. Текст томосу перекладено й українською / С. Чорна // Голос України. 2019. 19 січ.

\title{
REPRESENTATION OF TOMAS ABOUT THE AUTOCEPHALY OF THE ORTHODOX CHURCH OF UKRAINE IN THE PRESS
}

\author{
Oksana Hotsur \\ Ivan Franko National University of Lviv, \\ Generala Chuprynky Str., 49, 79044, Lviv, Ukraine \\ e-mail: o hotsur@ukr.net \\ https://orcid.org/0000-0002-6589-0011
}

The article analyzes the topic of tomos on the pages of all-Ukrainian periodicals. The paradigm of the press problem concerning the coverage and accentuation of the issue of autocephaly of the Orthodox Church of Ukraine is being clarified.

The information and genre specifics, the nature of publications are considered. The press, which we studied differently, according to the focus on the readers, was publishing the materials. Analytically, the intellectual issues of the «День», «Дзеркало тижня», «Урядовий кур'єр» and the «Голос України» were used to highlight the topic. The «Україна молода» and «Молодь України» publications also published their materials in great detail.

The dynamics of the appearance of materials in the press was traced. The positive dynamics that lasted from April 2018 to the provision of the document on autocephaly of the Orthodox Church of Ukraine predetermined the very fact of the historical importance of the moment and, in general, the opportunity for Ukraine to such an event.

On the basis of the materials, the concepts of the tomos are singled out: «second independence», «geopolitics», «new beginning», «historical community», «maternal church»; and binary Opposition («Ukraine-Russia», «Ukrainian Orthodox Church of the Kyiv Patriarchate Ukrainian Orthodox Church of the Post-Soviet Patriarchate»).

Key words: press, concept, publication, autocephaly, tomos, Orthodox Church of Ukraine, Ukrainian Orthodox Church of Kyiv-Patriarchate, Ukrainian Orthodox Church of the PostSoviet Patriarchate. 